\title{
Chapter 10 \\ Valuation of Non-Marketed Agricultural \\ Ecosystem Services, and Food Security \\ in Southeast Asia
}

\author{
Ryohei Kada
}

\begin{abstract}
Food security, closely linked with environmental issues, has become one of the most important issues in the twenty-first century. In recent decades especially, ecological degradation has been spreading, and is negatively affecting food supply and food safety conditions in many Southeast Asian countries. Such degradation can include sedimentation, reduced water quality, and frequent flood occurrence, many of which are enhanced by climate change impacts. Based on an international research project conducted by RIHN (Research Institute for Humanity and Nature) in collaboration with Yokohama National University and the University of the Philippines, we discuss the recent changes in food risks and the factors contributing to expansion of such risks in Southeast Asia. Our study demonstrates that non-marketed ecosystem services from sustainable agricultural land use can provide significant economic value, and developing a mechanism to pay for ecosystem services is crucial in enhancing sustainable agricultural development.
\end{abstract}

Keywords Ecological degradation • Ecosystem services • Resource management - Southeast Asia $\bullet$ Valuation of non-marketed services

\subsection{Food Security Issues in Southeast Asia}

Many Asian countries increased agricultural and food production in the course of their rapid economic development, leading to extensive degradation of natural resources and the reduction of ecosystem services. Such unsustainable patterns of development gradually endanger biodiversity and ecosystem services that are crucially important in Southeast Asia.

\footnotetext{
R. Kada $(\square)$

Research Institute for Humanity and Nature (RIHN), Kyoto, Japan

Graduate School of Environment and Information Sciences,

Yokohama National University, Yokohama, Japan

e-mail:kada@ynu.ac.jp; kada@chikyu.ac.jp
} 
The basic issue here is whether and how Asian agriculture and fisheries can supply a sufficient amount and quality of food stably to meet the needs of the rapidly growing population without jeopardizing natural and environmental resources.

Probably the most critical impacts of resource degradation are on food security for the poorer populations in rural Asia. On the other hand, environmental regulations to combat such resource degradation might increase the cost of production and decrease farmers' net returns for some commodities in the short-run. Lower returns might also alter the pattern of agricultural products and initiate new directions in domestic production and international trade.

It has been estimated that food production must rise $50 \%$ to feed nine billion people by 2050 (FAO 2008). The increased population growth accompanied by significant land use change will substantially reduce the availability of non-marketed ecosystem services, threaten agricultural sustainability, rapidly alter the global climate, and soon put human well-being at serious risk.

Can we take up the global challenge? This study demonstrates that taking some steps at a local level may help significantly in ensuring agricultural sustainability, helping to mitigate climate change, and maintaining human well-being at a global level. Such steps should include recognizing and estimating the value of nonmarketed ecosystem services and creating payment for such services.

Agriculture supplies ecosystem services including marketed goods such as food and fiber, and non-marketed services such as flood regulation, disease control, water purification, and scenic views. People generally assume that the non-marketed ecosystem services, which are not traded in traditional markets, have no economic significance (Daily and Ellison 2002). In recent years, agriculture in Asia especially has experienced significant land use change and soil degradation due to urbanization, non-agricultural practices, deforestation, and overexploitation of agricultural resources as a result of population growth. Consequently, the level of non-marketed ecosystem services has drastically reduced, giving rise to ecological risks. Studies estimating the values of non-marketed ecosystem services that emerge from agriculture are still inadequate, and consequently, the decision-making process involving agricultural sustainability and food security has remained flawed.

Given this, our study demonstrates that non-marketed ecosystem services from agriculture can have significant economic value, and developing a mechanism to pay for ecosystem services is crucial in enhancing sustainable agricultural development. Furthermore, failing to accommodate non-market values in the decisionmaking process for agricultural development can even threaten agricultural sustainability and human well-being by generating considerable externalities and ecological risks, as well as market failures.

\subsection{Need for Valuing Non-Marketed Ecosystem Services}

In this study, we have used the classification of ecosystem services devised by Millennium Ecosystem Assessment (Millennium Ecosystem Assessment (MEA) 2005) (Fig. 10.1), and illustrated a number of valuation methods for non-marketed 


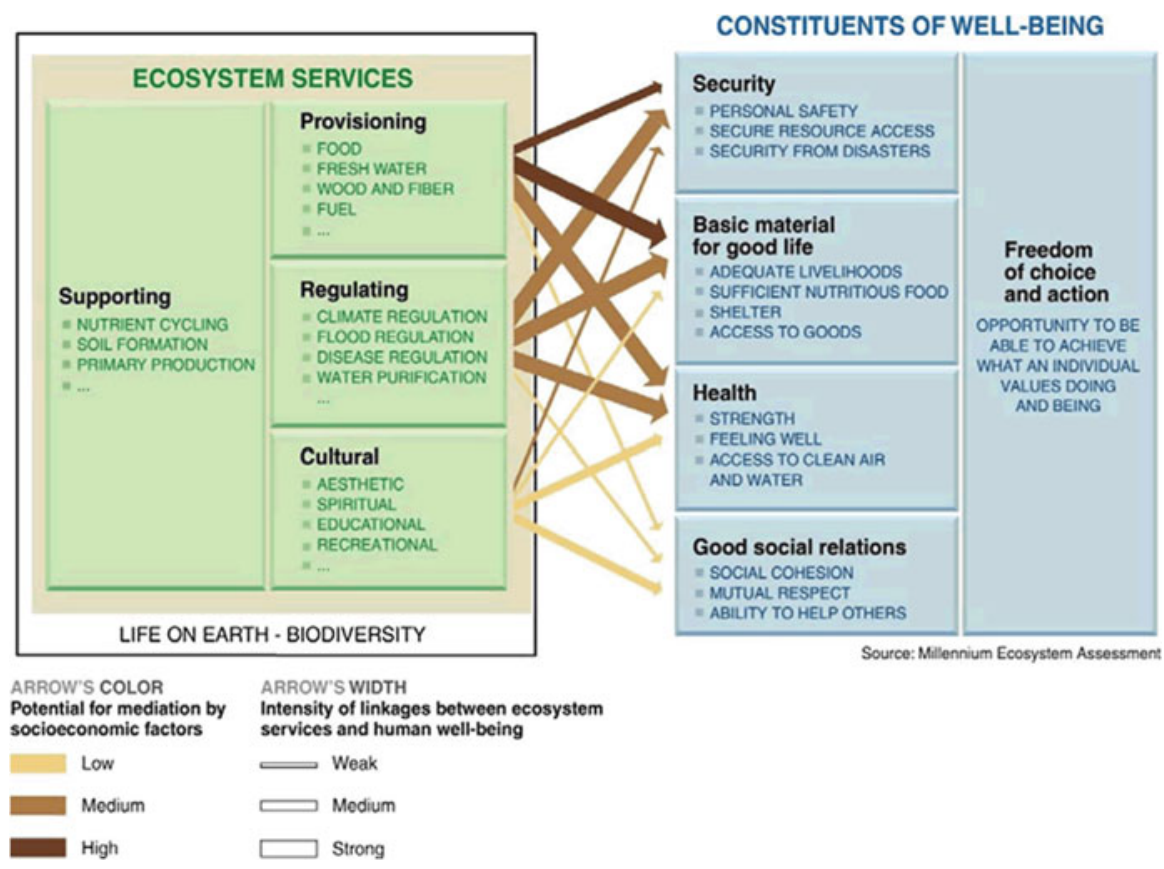

Fig. 10.1 Classification of ecosystem services (Source: Millennium Ecosystem Assessment (MEA) (MEA) (2005))

ecosystem services stated in Pearce and Howarth (2000). This classification includes supporting, provisioning, regulating, and cultural services. The supporting services maintain the other three, which are linked to human well-being. In line with this, we have illustrated international examples of payment for ecosystem services and demonstrated how estimating the economic value of ecosystem services and developing a mechanism for payment involving beneficiaries and providers could help address issues associated with economic externalities, ecological risks, and market failures, and subsequently, enhance human well-being. Ecosystem services, which are defined as the benefits provided from nature to humans, include supporting services such as primary production and soil formation, provisioning services such as food and water, regulating services such as flood and disease control, and cultural services such as recreational benefits (Millennium Ecosystem Assessment (MEA) 2005) (Fig. 10.1). Supporting services maintain the other three services.

Human actions, externalities, ecological risks, and human well-being are well interlinked. This means that when human actions reduce the level of ecosystem services, ecological risks emerge as a distribution of potential negative externalities. An externality is generally defined as an action of an individual or a group of individuals that inflicts a cost or benefit on others. A human action can have both negative and positive impacts on others. For example, when a farmer uses an excess amount of chemical fertilizers on his or her land, the nearby water body becomes 
Table 10.1 Degradation of ecosystem services and ecological risks in Asia

\begin{tabular}{|c|c|c|c|}
\hline $\begin{array}{l}\text { Reduction } \\
\text { in ecosystem } \\
\text { services (ES) } \\
\end{array}$ & $\begin{array}{l}\text { Ecological risks due } \\
\text { to a reduced level of ES }\end{array}$ & $\begin{array}{l}\text { Human activities } \\
\text { reducing ES }\end{array}$ & $\begin{array}{l}\text { Countries in Asia } \\
\text { where ecological } \\
\text { risks are highly likely }\end{array}$ \\
\hline $\begin{array}{l}\text { Supporting } \\
\text { - } \quad \text { Nutrient cycling } \\
\text { - } \text { Soil formation } \\
\text { - } \text { Primary } \\
\quad \text { production }\end{array}$ & $\begin{array}{l}\text { Poor soil quality } \\
\text { Destruction of genetic } \\
\text { resources such as fish, } \\
\text { frogs, and earth worms } \\
\text { in paddy fields }\end{array}$ & $\begin{array}{l}\text { Use of chemical } \\
\text { fertilizers } \\
\text { Use of chemical } \\
\text { insecticides } \\
\text { Introduction of } \\
\text { aquaculture }\end{array}$ & $\begin{array}{l}\text { Bangladesh, India, } \\
\text { Indonesia, Nepal }\end{array}$ \\
\hline $\begin{array}{l}\text { Provisioning } \\
\text { - } \quad \text { Food } \\
\text { - } \text { Fresh water } \\
\text { - Wood and fiber } \\
\text { - } \quad \text { Fuel }\end{array}$ & $\begin{array}{l}\text { Food insecurity } \\
\text { Water pollution } \\
\text { Soil erosion }\end{array}$ & $\begin{array}{l}\text { Conversion of } \\
\text { agricultural land } \\
\text { for human } \\
\text { settlements } \\
\text { Deforestation }\end{array}$ & $\begin{array}{l}\text { Bangladesh, India, } \\
\text { Nepal, Indonesia, } \\
\text { the Philippines, } \\
\text { Sri Lanka }\end{array}$ \\
\hline $\begin{array}{l}\text { Regulating } \\
\text { - } \text { Climate } \\
\text { regulation } \\
\text { - } \\
\text { - } \text { Dlood regulation } \\
\text { regulation } \\
\text { - Water } \\
\text { purification }\end{array}$ & $\begin{array}{l}\text { GHG emissions } \\
\text { Flooding } \\
\text { Public health hazards } \\
\text { Water Pollution }\end{array}$ & $\begin{array}{l}\text { Extension of oil } \\
\text { palm and sugar } \\
\text { cane plantations }\end{array}$ & $\begin{array}{l}\text { Indonesia, Malaysia, } \\
\text { the Philippines }\end{array}$ \\
\hline $\begin{array}{ll}\text { Cultural } \\
\text { - } & \text { Aesthetic } \\
\text { - } & \text { Spiritual } \\
\text { - } & \text { Educational } \\
\text { - } & \text { Recreational } \\
\end{array}$ & $\begin{array}{l}\text { Reduced aesthetic appeal } \\
\text { Loss of recreational } \\
\text { amenities } \\
\text { Less communication } \\
\text { among people }\end{array}$ & $\begin{array}{l}\text { Use of chemical } \\
\text { fertilizers } \\
\text { Use of chemical } \\
\text { insecticides }\end{array}$ & Bangladesh, India \\
\hline
\end{tabular}

polluted and biomass resources will be gradually lost due to the reduction in ecosystem services such as water purification. However, there is no obligation to compensate for loss of ecosystem services; consequently, the farmer does not pay for the damage that he or she inflicts on the owner of the water body. Similarly, there is no requirement for the owner of the water body to pay the farmer (as the owner of the land) if he or she abstains from using chemical fertilizers (the absence of which could inhibit the farmer's production).

As shown in Table 10.1, human activities such as use of chemical fertilizers and insecticides, and conversion of agricultural land for human settlements, can generate ecological risks. These include poor soil quality, water pollution, and food insecurity resulting from reduced ecosystem services, especially provisioning services.

In Indonesia serious land use changes occur as a result of rapid expansion of oil palm plantations that replace ecologically valuable tropical rainforest and mangrove. This is a situation in which human action causes $\mathrm{CO}_{2}$ emission responsible for climate change and global warming. Furthermore, clearance and draining of peatland enhances fire and causes carbon stock to emit $\mathrm{CO}_{2}$ into the atmosphere. Although the country's economic development is essential, therefore, the ecological risks associated with the development are pervasive. 
Likewise in Malaysia land use changes occur due to expansion of palm oil production, and the changes exacerbate crises already caused by deforestation, ecosystem degradation, and biodiversity loss. The country currently faces serious issues involving the trade-off between oil-palm growth and maintenance of ecosystem services. Furthermore, many ecological risks have emerged in the agricultural sector, such as water supply shortages, soil erosion and fertility loss, water-logging effects, salinity, and mangrove conversion. In order to manage these ecological risks, the country instituted a range of legal and regulatory measures such as the National Environmental Policy, the National Conservation Strategy, the National Policy on Biological Diversity, and the Environmental Quality Act.

In the Philippines, human-induced ecological risks occur due to land use changes in wetlands. Wetlands are important for both humans and birds. Although particular areas are set aside as bird sanctuaries by local governments with cooperation from local communities, there is growing pressure for cultivated wetland areas to meet the increasing needs of humans for food and fiber. To increase food production in cultivated areas more water is required, and this aggravates water pollution and soil erosion, while reducing carbon sequestration. Consequently, the pressure on cultivated areas reduces the level of ecosystem services. Like other countries, the Philippines is trying to balance agricultural production with supply of ecosystem services, but efforts to do so are affected by typhoons, drought, floods, and social unrest. To address the issues of ecological risks, the country has introduced a wide range of environmental laws and policies on land use management and agrarian reforms, with greater priority placed on community-based management. However, policies related to national land use are not on the agenda and this has caused confusion and conflicts on the part of implementing agencies and authorities.

Recent expansion of bio-energy production, which has occurred indiscriminately and on a major scale, has resulted in new environmental obstacles, especially in Indonesia, Malaysia, and the Philippines. Typically, the expansion of oil palm, coffee, or banana plantations has caused massive deforestation and a loss of biodiversity that could include precious genetic resources found only in tropical Asia. Ironically, $\mathrm{CO}_{2}$ emission in plantation crops occurs at a considerably higher rate than in the conventional crops and grains.

Goda et al. (2006) have listed a number of negative externalities that ultimately result from human activities such as degradation, livestock production, and use of pesticides in agriculture. Due to population growth and rapid economic development, many Asian countries have increased agricultural food production. However, these human activities have resulted in extensive degradation of natural resources and the reduction of ecosystem services. In particular, the adoption of modern technology including intensive use of fertilizers and monoculture has caused serious soil and water degradation. For example, substantial soil degradation has resulted from deforestation (30\%), overcultivation (32\%), and overgrazing (26\%) occurring due to population growth and economic development in the Asian region.

In Japan, the decrease in farmland area has caused various social problems. Due to both rapid urbanization and abandonment of farmland, ecosystem services from farmlands have been lost, resulting in more frequent occurrences of flooding in the 
surrounding areas and city areas downstream. Although chemical fertilizer input is an essential element of enhancing productivity, an excessive use of chemical inputs in the long run has resulted in negative externalities such as water pollution and biodiversity loss.

Groundwater contamination due to crop and livestock production activities has become an important public issue in some areas of Japan. Nitrates are a major source of water contamination, introduced not only through the use of chemical fertilizers, but also associated with the amalgamation of animal manure.

Similarly, pesticide residues can be toxic to humans and animals in food, feed, or drinking water. They also may be hazardous to farm workers during application and have undesirable side effects on non-targeted living organisms within the natural ecosystem.

It is of considerable importance to develop a mechanism to pay for ecosystem services involving the beneficiaries and producers of such services in the agricultural sector. This could address the externality and market failure issues in agriculture, and consequently, increase food production in a sustainable way.

Intensive livestock production systems, especially confinement livestock operations, accumulate large amounts of animal waste in solid and liquid forms. Manure, in concentration or untreated, can be considered a potential hazard to the environment due to its high content of nitrate, ammonia, phosphate, and potassium. As manure decomposes, various microelements (zinc, copper, manganese, iron, etc.) are released directly into surface rivers and lakes, or are leached through the soil to groundwater sources. Other things being equal, high animal densities indicate strong potential for pollution problems that could translate into higher costs of production if waste management costs rise. Such high densities are frequently associated with technological developments found in modernized, large-scale livestock operations, as well as in China and other developing countries.

What all these consequences imply is that we need to estimate the values of nonmarketed ecosystem services and develop a mechanism to pay for them in order to address such issues.

\subsection{Issues of Valuation and Payment for Non-Marketed Ecosystem Services}

Estimating the economic values of non-marketed ecosystem services is a challenging issue. There are a number of approaches available to estimate the values, and the selection of a particular approach is problematic. In addition, such estimation requires significant knowledge regarding the provision, distribution, and valuation of non-marketed ecosystem services. Nonetheless, it is of considerable benefit to develop some form of valuation approach.

Figure 10.2 demonstrates that many approaches exist to estimate economic values of environmental goods and services, as illustrated by the satoyama and satoumi cases. Total Economic Value (TEV) comprises revealed (conventional market) and stated (hypothetical market) preferences. 


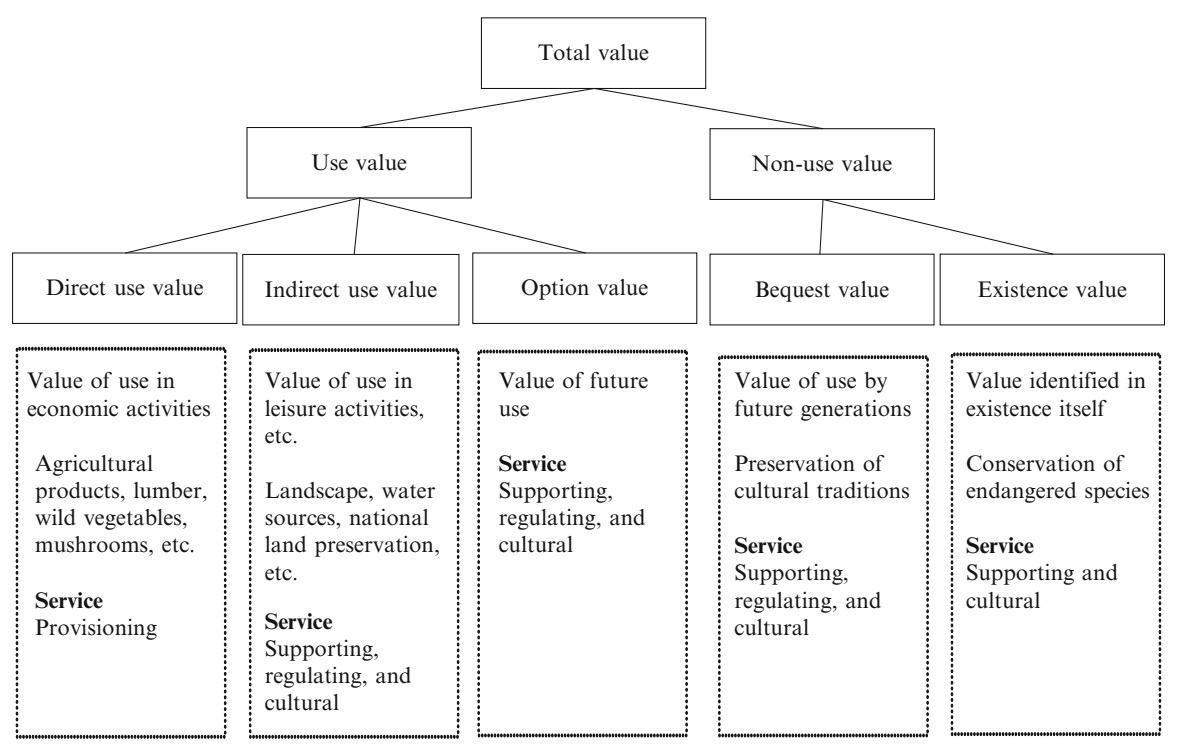

Fig. 10.2 Typology of economic values and relevant ecosystem services of satoyama and satoumi (Kada et al. 2012)

\subsubsection{Revealed Preferences (Conventional and Surrogate Markets)}

Revealed preferences methods use existing markets for relevant goods and services with a view to revealing TEV of environmental qualities. For most regular, tradable goods in a market, the use-values are significant and TEV is determined principally by the use value of the goods as revealed by their market price. However, the nonuse value may be highly significant because people may value an environmental good for its existence and capacity to support sustainable livelihoods for current and future generations. The major drawback of the revealed preference method when compared to the stated preference method is its inability to accommodate and measure these non-use values.

Two of the commonly practiced methods in the revealed preferences group are Hedonic Pricing and Travel Cost Methodologies.

1. Hedonic Pricing Method (HPM): A hedonic pricing approach is used to estimate economic values of ecosystem services (i.e., benefits from nature) that affect market prices. The approach involves the quality of the environment and ecosystem (such as the degree of air pollution and noise) and environmental amenities (e.g., aesthetic views, or distance to the central business district, recreational sites such as botanical gardens, and hospitals). The Hedonic Pricing Method (HPM) assumes that differences in amenities for the housing environment are 
reflected in land prices and wages. By this hedonic pricing approach it is estimated that Japan's paddy field amenities are worth approximately JPY 12 trillion.

2. Travel Cost Method (TCM): The travel cost method or approach is a way to estimate economic values of recreational sites. This approach is used to analyze nature-based recreation demand and estimate economic values of the natural resources. The TCM is widely used to estimate the value of recreational sites and could be used to estimate willingness to pay (WTP) for ecotourism to visit world heritage sites such as the Ifugao Rice Terraces in the Philippines.

In Concepcion (2006) we find that a socio-economic team used the TCM to evaluate the agri-tourism function of agriculture in mango orchards in the Philippines. They used the formula: Valuation $=$ (number of domestic and foreign tourists) $\times$ (average opportunity cost of work + average cost per visit + average value of mangoes and souvenir items bought), where the number of tourists is 13,322, average travel cost is USD 36.62, average opportunity cost is USD 18.69 , average accommodation cost is USD 14.79, and average cost of mangoes and other souvenir items is USD 23.42 .

\subsubsection{Stated Preferences (Hypothetical Preferences)}

The stated preferences approach is primarily survey-based and depends largely on what the respondents say rather than what they do. The approach posits a hypothetical market or payment scenario involving unpriced environmental goods and services, asks respondents to place a dollar value on goods and services, and draws conclusions about respondents' willingness to make payment for some specific attributes of the goods and services.

The stated preferences group includes contingent valuation, and conjoint analysis.

1. Contingent Valuation $(C V)$ : $\mathrm{CV}$ was developed. The main purpose of $\mathrm{CV}$ is to estimate people's Willingness to Pay (WTP) or Willingness to Accept (WTA) based on a single feature (rather than multiple features) of an environmental good. This approach asks people to state their willingness to pay, and is contingent on a specific hypothetical market scenario.

2. Conjoint Analysis (CA): CA is a statistical technique used to find out how people value multiple features of an individual environmental good.

CA may include Contingent Ranking, Contingent Rating, Paired Comparison, and Choice Modeling which are closely related approaches to environmental valuation.

The most important ecosystem service from agriculture is perhaps food security, while we must also maintain agricultural sustainability. Due to soil degradation and 
water pollution, small farmers and poor city dwellers encounter poverty and food insecurity all over the world.

Kada (2012) identified the potential and challenges in developing payment for ecosystem services in Japan, as follows:

- An increasing number of individuals and groups from cities are willingly assisting farmers and rural communities with their work, while at the same time enjoying the rural amenities.

- The Japanese Ministry of Agriculture, Forestry and Fisheries (MAFF) has introduced a direct payment scheme for farmers and rural communities to maintain the existence of paddy fields.

- To create ecologically-friendly wetlands, parks, and ponds in harmony with agricultural activities, attempts have been made on both a public and a voluntary basis to undertake groundwork activities and create trusts to conserve the landscape and preserve genetic resources (e.g., insects, fish, birds, and flora).

- Consumers and producers are affiliating to support regional agriculture through contracts between the two parties for fresh and safe farm products. Direct marketing systems such as farmers' markets and producer-consumer affiliated marketing have become very popular in Japan today.

- There has been an expansion in green tourism, whereby city dwellers are invited to spend their leisure time visiting rural landscapes, enjoying farming experiences, farming for their own consumption, and voluntarily working in forests and paddy fields in remote rural areas.

- Local governments are providing direct support for environmentally-friendly farming through direct subsidies to farmers who keep paddy fields for flood mitigation purposes. To be eligible for this subsidy, the local government requires that the owners of paddy fields sign a contract to maintain the paddy land or farmland.

As shown in Fig. 10.2, non-marketed ecosystem services derived from agricultural and rural areas can be measured. The table measures regulating services, such as prevention of floods, soil erosion, and landslides, as well as cultural services, such as recreation and relaxation.

What this implies is that estimating economic values for non-marketed ecosystem services is possible, if imprecise. What is more, estimating economic values is crucial in creating a market for ecosystem services (payment for ecosystem services). Both non-coercive government intervention and cooperation from the natural resource users would appear to be essential in establishing such a market. In order to maintain the level of non-marketed ecosystem services provided by agriculture, therefore, it is important to assist farmers with new technology that requires a reduced amount of chemical fertilizers and insecticides, reduces the conversion of agricultural land use into non-agricultural, and compensates farmers for conserving agricultural land. 


\subsection{Conclusion}

Although food production must increase to feed the burgeoning population, it is possible to maintain agricultural sustainability to an extent by estimating the values of non-marketed ecosystem services and creating a market for such services (i.e., a mechanism to pay for ecosystem services). This will both maintain the availability of ecosystem services and enhance human well-being.

Agriculture provides not only marketed ecosystem goods (e.g., food and fiber), but also non-marketed ecosystem services (e.g., water purification, disease control, and scenic views). People have usually ignored the economic significance of the ecosystem services and considered them to be unlimited. However, as the overexploitation of agricultural resources has reduced the level of non-marketed ecosystem services and diminished human well-being, people have started to recognize that such ecosystem services are finite, and have economic values. They have also understood that valuing these ecosystem services is crucial in creating a market for them.

Past studies recognized that non-marketed ecosystem services have economic values, and developed a number of approaches to estimate those values, but making precise estimates still remains a challenging task. Although the estimates are far from precise, however, the recognition of value in itself has profound policy implications in terms of enhancing food security and making agricultural development more sustainable by addressing externalities, ecological risks, and market failures. Thus, taking up appropriate action at the local level will help us counter the global challenges.

Open Access This article is distributed under the terms of the Creative Commons Attribution Noncommercial License which permits any noncommercial use, distribution, and reproduction in any medium, provided the original author(s) and source are credited.

\section{References}

Concepcion RN (2006) Emerging roles of land and water management and agri-tourism to enhance the multifunctionality of agriculture in the Philippines. Country case studies on multifunctionality of agriculture in ASEAN countries. The ASEAN Secretariat, Ministry of Agriculture, Forestry and Fisheries of Japan, Jakarta

Daily GC, Ellison K (2002) The new economy of nature: the quest to make conservation profitable. Shearwater Books/Island Press, Washington, DC

FAO (2008) Ecosystem services sustain agricultural productivity and resilience. Plant Production and Protection Division. Food and Agriculture Organization, Rome

Goda M, Kada R, Yabe M (2006) Concept and significance of multifunctionality of agriculture: a global perspective. Country case studies on multifunctionality of agriculture in ASEAN countries. The ASEAN Secretariat, Ministry of Agriculture, Forestry and Fisheries of Japan, Jakarta

Kada R (2012) Opportunities and challenges for rebuilding and effective use of satoyama resources. Glob Environ Res 16(2):173-179 
Kada R, Kohsaka R, Saito O (2012) Why is change to satoyama and satoumi a concern? In: Duraiappah AK et al (eds) Satoyama-satoumi ecosystems and human well-being. United Nations University Press, Tokyo/New York

Millennium Ecosystem Assessment (MEA) (2005) Ecosystems and human well-being: synthesis. Island Press, Washington, DC

Pearce DW, Howarth A (2000) Technical report on methodology: cost benefit analysis and policy responses. RIVM report 